\title{
REPRESENTASI TOKOH WANITA DALAM CERPEN OLEH SISWA SMP SWASTA SANTA LUSIA SEI ROTAN
}

\author{
Dormauli Sigiro ${ }^{1,}$ Adelina Ginting ${ }^{2}$ \\ *1. Penulis \\ *2. Pembimbing \\ Program Studi Pendidikan Bahasa Indonesia, Fakultas Keguruan dan Ilmu Pendidikan, Universitas Katolik \\ Santo Thomas, Jl. Setia Budi No. 479-F Tanjung Sari Medan-Kode Pos No. 20132, email-odouli@ymail.com
}

\begin{abstract}
Abstrak
Penelitian ini, bertujuan untuk merepresentasi tokoh wanita dalam cerpen Martini karya Kurniawan Lastanto. Penelitian ini dilakukan di SMP Swasta Santa Lusia Sei Rotan pada bulan Mei 2018. Subjek penelitian berjumlah 30 siswa. Metode yang digunakan dalam penelitian ini adalah metode deskriptif kualitatif yaitu mendeskripsikan atau menggambarkan karakter tokoh dalam cerpen. Cerpen Martini menceritakan tentang masalah kehidupan umum zaman sekarang dan tentang perjuangan seorang ibu rumah tangga dalam kehidupan keluarganya di negeri orang. Hasil penelitian ini menunjukkan bahwa pesan yang disampaikan oleh Kurniawan Lastanto lewat cerpen Martini adalah berpikir positif, sebagai seorang suami harus bertanggung jawab terhadap keluarga, sabar dan tekun dalam menjalani kehidupan dan selalu punya niat baik dalam hidup. Representasi tokoh wanita dalam cerpen Martini adalah Representasi tokoh Martini, wanita itu pekerja keras, lembut, sabar dan tabah, penurut, berpikir positif, setia, dan juga pemarah. Representasi tokoh Mbok (Ibu Martini) tidak mau terus terang, sabar, dan lemah lembut. Representasi tokoh Istri baru seorang perebut laki orang, kasar dan tidak peduli. Perhitungannya adalah (1) Tokoh Martini : siswa yang mendapat poin 8 ada $2=(2 / 30 \times 100 \%) 6,66 \%$ siswa, siswa yang mendapat poin 7 ada $7=23,33$ siswa, siswa yang mendapat poin 6 ada $9=30 \%$ siswa, siswa yang mendapat poin 5 ada $4=13,33 \%$ siswa, siswa yang mendapat poin 4 ada $2=6,66 \%$ siswa, siswa yang mendapat poin 2 ada $6=20 \%$ siswa. (2) Tokoh Mbok (ibu Martini): siswa yang mendapat poin 3 ada $5=16,66 \%$ siswa, siswa yang mendapat poin 2 ada $10=33,33 \%$ siswa, siswa yang mendapat poin 1 ada $15=50 \%$ siswa. (3) Istri Baru : siswa yang mendapat poin 2 ada 5 $=16,66 \%$ siswa, siswa yang mendapat poin 1 ada $22=73,33 \%$ siswa, dan ada $3=10 \%$ yang tidak menemukan representasi tokoh istri baru. Implikasi penelitian ini adalah bahwa adanya hubungan yang positif antara kebiasaan membaca cerpen dan pemahaman unsur intrinsik dengan kegiatan merepresentasi tokoh wanita atau tokoh-tokoh yang ada dalam cerpen. Peneliti menyarankan agar kemampuan siswa dalam menganalisis unsur intrinsik merepresentasi tokoh-tokoh dalam cerpen perlu ditingkatkan melalui pembelajaran yang menarik dan menyenangkan agar daya tangkap dan respon dari siswa ke guru dan guru ke siswa dapat berjalan dengan baik.
\end{abstract}

Kata Kunci : Representasi, Cerpen, Tokoh Wanita.

\begin{abstract}
This research aims to represent the female characters in short story of Martini by Kurniawan Lastanto. The research was conducted at Private Junior High School of Santa Lusia Sei Rotan in May 2018. The subject of this research were 30 students. The method used ISSN 15421-71667
\end{abstract}

Volume 1 Nomor 1 Desember 2018 
in this research is descriptive qualitative method that is describe character of participants in the short story. This short story tells about the problems of public life today and about the struggle of a housewife in her family life in another country. The result of this study indicate that the message delivered by Kurniawan Lastanto through Martini's Short Story is be positive thinking. A husband must be responsible to the family, patient, and diligent in living life and always have good intentions in life. Representation of the female character in the Martini Short Story is the representation of Martini, the woman is a hard working, gentle, patient and steadfast, obedient, positive thinking, loyal, and also angry. Representation of 'Mbok' (Mrs. Martini) figure does not want to be frank, patient, and meek. Representation of the new wife figure of a man's snatcher, rude and uncaring. The caculation is (1) Martini character : total students who got 8 points are $2=6.66 \%$ students, who got 7 point are $7=$ $23.33 \%$ students, who got 6 points are $9=30 \%$ students, who got 2 points are $6=20 \%$ students. (2) Mbok (Martini's mother) character : total students who got 3 points are $5=$ $16.66 \%$ student, who got 2 points are $10=33.33 \%$ students, who got 1 points are $15=50 \%$ student. (3) New Wife character : total students who got 2 points are $5=16.66 \%$ students, who got 1 points are $22=73.33 \%$ students, and there are $3=10 \%$ which did not represent the new wife character. The implication of this research is that there is a positive correlation between the habit of reading short stories and the understanding of intrinsic elements with the activities of representing female character or characters in the short story. The researcher suggested that students ability in analyzing the intrinsic elements representing the characters in the short story needs to be improved through interesting and fun learning so that the understanding and the response from students to teachers and teachers to students can run well.

\section{Key words: Representation, Short Story, and Female Character}

\section{PENDAHULUAN}

$\begin{array}{lllr}\text { Sastra } & \text { lahir } & \text { disebabkan } & \text { oleh } \\ \text { dorongan dasar } & \begin{array}{c}\text { manusia } \\ \text { untuk }\end{array} & \begin{array}{r}\text { dirinya. } \\ \text { mengungkapkan }\end{array}\end{array}$ Perhatian besar terhadap masalah manusia dan kemanusiaan serta perhatiannya terhadap dunia realitas yang berlangsung tiap hari dan sepanjang zaman. Oleh sebab itu, sastra yang telah dilahirkan oleh para pengarang diharapkan dapat memberikan kepuasan estetik dan intelektual bagi masyarakat pembaca. Karya sastra merupakan media yang digunakan pengarang untuk menyampaikan gagasangagasannya. Karya sastra menjadi media transformasi informasi dari pengarang kepada pembaca. Selain itu, karya sastra diciptakan pengarang untuk dimaknai oleh pembaca. Akan tetapi, sering terjadi bahwa karya sastra tidak dapat dipahami serta dinikmati sepenuhnya oleh masyarakat pembaca. Penciptaan karya merupakan refleksi pandangan pengarang terhadap berbagai masalah yang terjadi di sekitar lingkungannya. Realitas sosial itu ISSN 15421-71667

Volume 1 Nomor 1 Desember 2018 dituangkan oleh pengarang dalam sebuah teks sehingga teks-teks itu merupakan gambaran fenomena sosial yang akan dibaca dan dimaknai oleh pembaca. Pengertian karya sastra adalah untaian perasaan dan realitas sosial (semua aspek kehidupan manusia) yang telah tersusun baik dan indah dalam bentuk benda konkret seperti tulisan, dan dapat juga berbentuk tuturan atau yang dikenal sebagai karya sastra lisan.

Karya sastra yang dibahas dalam penelitian ini bergenre cerita pendek. Karya sastra dalam bentuk cerpen menceritakan potret kehidupan masyarakat di sekitar pengarang biasanya merupakan kenyataan sosial, yang sedang dirasakan pengarang atau yang sudah terjadi dalam kehidupan masyarakat tersebut. Cerita pendek sering kali mengambil tema-tema sederhana yang terjadi dalam kehidupan masyarakat. Ada pengarang yang mengambil tema-tema sosial, mengenai 
kehidupan perempuan serta menuliskannya dalam karya sastranya itu. Tema dan topik yang menarik untuk dibaca, adalah tema yang mengangkat kenyataan sosial yang timbul dan berkaitan dengan kehidupan serta kodrat manusia sebagai makhluk sosial dalam kehidupan. Beragamnya tema yang mengangkat persoalan-persoalan kehidupan manusia banyak ditampilkan dalam karya sastra. Tema yang menarik adalah tema yang mengangkat persoalan kehidupan perempuan yang mengalami kekerasan dan ketidakadilan. Karya sastra yang mengangkat tema mengenai masalah kekerasan terhadap perempuan , kesetaraan gender yang sering dialami perempuan, juga ketidakadilan gender yang dialami perempuan merupakan tematema feminisme, karya sastra tersebut sangat menarik untuk dibaca dan dianalisis menggunakan teori kritik sastra feminis.

Feminisme berarti gerakan yang menuntut persamaan hak sepenuhnya antara kaum perempuan dan laki-laki (KBBI, 2008: 390). Kehidupan perempuan dapat dilihat dari sisi positif serta negatif. Dari sisi positif perempuan memiliki keahlian dalam suatu bidang tertentu yang tidak dimiliki oleh laki-laki, yaitu mengatur rumah tangga, mengurus anakanak dan melayani suami, sedangkan sisi negatifnya, perempuan berkonotasi sebagai alat pemuas laki-laki dan dapat disiasiakan, serta diperlakukan secara tidak adil oleh laki-laki. Berbagai ketidakadilan gender terhadap perempuan beserta kedudukannya muncul di dalam masyarakat. Adanya anggapan bahwa kedudukan atau posisi yang dianggap lemah dan tidak penting menyebabkan perempuan tidak memiliki kepercayaan diri serta kebebasan untuk menentukan pilihan dalam kehidupannya sendiri.

Pengkajian representasi perempuan melalui tokoh utama dalam cerpen Martini karya Kurniawan Lastanto sangat menarik untuk dilakukan. Representasi ini akan memberikan paradigma baru terhadap apa yang selama ini yang digambarkan oleh ISSN 15421-71667

Volume 1 Nomor 1 Desember 2018 kaum pria tentang perempuan yang dikonstruksi oleh kaum patriarkhi. Paradigma baru tersebut berupa sudut pandang perempuan dalam menilai perempuan melalui karya sastra yang diciptakan oleh pengarang.

Representasi merujuk pada bagaimana seseorang, satu kelompok, gagasan atau pendapat tertentu ditampilkan dalam isi sebuah teks. Sara Mills menyatakan bahwa representasi perempuan dalam teks yang diproduksi, biasanya cenderung tidak sesuai dengan hal yang sesungguhnya. Perempuan condong ditampilkan sebagai pihak yang marjinal dibandingkan laki-laki dalam kebanyakan film. Perempuan perlu dilihat penggambarannya, sebab penggambaran yang ditampilkan nantinya akan mempengaruhi bagaimana pembaca melihat realita. Untuk itu penelitian tentang representasi perlu dilakukan guna melihat bagaimana tokoh perempuan digambarkan di dalam sebuah cerpen. Dilatarbelakangi fakta-fakta tersebut, peneliti melakukan analisis terkait representasi tokoh perempuan di dalam cerpen Martini.

Cerpen Martini karya Kurniawan Lastanto, menceritakan tentang perjuangan dan kesabaran seorang perempuan dalam menjalani kehidupannya sebagai seorang ibu rumah tangga dan seorang istri bagi suaminya untuk membantu perekonomian keluarganya, sedangkan suaminya hanya duduk dan terima gaji buta. Cerita pada cerpen ini mempunyai kaitan yang sangat erat dengan kehidupan kita sehari-hari. Bahwa kebanyakan orang yaitu wanita pergi merantau ke negeri orang demi membantu perekonomian keluarga seperti menjadi Tenaga Kerja Wanita (TKW), sedangkan suaminya menunggu dirumah, untuk dikirimi uang dari istrinya tanpa berpikir, susahnya mencari uang dinegeri orang, sedangkan dia sendiri tidak bekerja. Namun, hal ini bertolak belakang dengan budaya serta tradisi, bahwa yang wajib mencari nafkah untuk keluarganya adalah 
suami. Karena suami adalah pemimpin dalam rumah tangga, jadi ia harus bertanggung jawab terhadap keluarganya.

Tokoh wanita dalam cerpen Martini ini ada tiga yaitu Martini, Mbok ibu Martini, dan wanita yang menjadi selingkuhan suami Martini. Tokoh utamanya adalah Martini, yang mempunyai watak yang sabar,lembut,pekerja keras, bertanggung jawab terhadap keluarga, hal ini di tunjukan dari penjelasan tokoh,penggambaran fisik tokoh serta tanggapan tokoh lain terhadap tokoh utama. Ia rela meninggalkan keluarganya demi membutuhi kehidupan ekonomi keluarganya. Sedangkan suaminya, adalah seorang yang tidak bertanggung jawab terhadap keluarganya.

\section{KAJIAN KEPUSTAKAAN Unsur Intrinsik}

1. Tema

Tema merupakan inti atau ide dasar sebuah cerita.

\section{Alur/plot}

Alur merupakan jalan cerita atau pola pengembangan cerita yang terbentuk dari hubungan sebab-akibat.

3. Latar/setting

Latar merupakan tempat, waktu, dan suasana terjadinya cerita.

\section{Tokoh/penokohan}

Tokoh adalah orang yang mempunyai peran dalam suatu karya sastra. Penokohan adalah cara pengarang menggambarkan dan mengembangkan karakter tokoh-tokoh dalam cerita.

5. Sudut pandang

Sudut pandang atau point of view adalah posisi pengarang dalam membawakan cerita.

\section{Amanat}

Amanat merupakan ajaran moral atau pesan yang hendak disampaikan pengarang kepada pembaca melalui karya sastra.

7. Gaya bahasa

Dalam cerita, penggunaan bahasa berfungsi untuk menciptakan suatu nada atau suasana persuasif serta merumuskan dialog yang mampu memperlihatkan hubungan dan interaksi antara sesama tokoh.

\section{METODELOGI PENELITIAN}

Penelitian terhadap karya sastra membutuhkan sebuah metode agar penelitian menjadi teratur dan terarah. Untuk menganalisis karya sastra secara lebih mendalam, peneliti menggunakan pendekatan deskriptif kualitatif. Data penelitian dideskripsikan berdasarkan kenyataan sebenarnya yang berupa tulisan kemudian dianalisis dan ditafsirkan secara objektif lalu dideskripsikan sesuai dengan tujuan penelitian. Penelitian kualitatif dilakukan dengan tidak mengutamakan pada angka-angka, tetapi mengutamakan kedalaman penghayatan terhadap interaksi antarkonsep yang sedang dikaji secara empiris.

Moleong (2016: 11) mengatakan bahwa penelitian deskriptif adalah penelitian yang bermaksud untuk memahami fenomena tentang apa yang dialami oleh subjek penelitian misalnya perilaku, persepsi, motivasi, maupun tindakan secara holistik, dan dengan cara deskripsi dalam bentuk kata-kata dan bahasa, pada suatu konteks khusus yang alamiah. Tujuan penulis memilih metode deskriptif kualitatif dalam menganalisis cerpen Martini karya Kurniawan Lastanto adalah untuk memberikan deskripsi atau gambaran dalam bentuk kata-kata tentang metode karakterisasi yang digunakan untuk menggambarkan tokoh wanita di dalamnya. Teknik pengumpulan data menggunakan langkah-langkahantara lain:

a. Teknik Observasi. Observasi adalah pengamatan dan pencatatan secara sistematik terhadap unsur-unsur yang tampak dalam suatu gejala atau gejala-gejala pada obyek penelitian”. Adanya observasi peneliti dapat mengetahui kemampuan siswa kelas VII SMP Santa Lusia Sei Rotan. Berdasarkan pemaparan di atas dapat ditarik kesimpulan bahwa observasi 
merupakan kegiatan pengamatan dan pencatatan yang dilakukan oleh peneliti guna menyempurnakan penelitian agar mencapai hasil yang maksimal.

b. Teknik Wawancara. Menurut Sugiyono (2010:194), Pengertian wawancara sebagai berikut:

Wawancara digunakan sebagai teknik pengumpulan data apabila peneliti akan melaksanakan studi pendahuluan untuk menemukan permasalahan yang harus diteliti, dan juga peneliti ingin mengetahui halhal dari responden yang lebih mendalam dan jumlah respondennya sedikit/kecil.

Wawancara yang digunakan dalam penelitian ini dengan mengajukan pertanyaan-pertanyaan terstruktur karena peneliti menggunakan pedoman wawancara yang disusun secara sistematis dan lengkap untuk mengumpulkan data yang dicari.

Wawancara pada penelitian ini dilakukan pada siswa SMP Santa Lusia kelas VII Sei Rotan. Metode wawancara yang digunakan untuk memperkuat dan memperjelas data yang diperoleh yaitu data tentang bagaimana merepresentasi tokoh wanita dalam cerpen. Wawancara merupakan suatu kegiatan yang dilakukan langsung oleh peneliti dan mengharuskan antara peneliti serta narasumber bertatap muka sehingga dapat melakukan tanya jawab secara langsung dengan menggunakan pedoman wawancara.

Dokumentasi.Metode dokumentasi adalah informasi yang berasal dari catatan penting baik dari lembaga atau organisasi maupun dari perorangan. Dokumentasi penelitian ini merupakan pengambilan gambar oleh peneliti untuk memperkuat hasil penelitian. Menurut Sugiyono (2013:240), dokumentasi bisa berbentuk tulisan, gambar atau karya-karya monu-mentel dari seseorang. Dokumentasi merupakan pengumpulan data oleh peneliti dengan cara mengumpulkan dokumen-dokumen dari sumber terpercaya yang mengetahui tentang narasumber. Metode dokumentasi menurut Arikunto (2006:231) yaitu mencari data mengenai variabel yang berupa catatan, transkrip, buku, surat kabar, majalah, prasasti, notulen rapat, agenda dan sebagainya. Berdasarkan kedua pendapat para ahli dapat ditarik kesimpulan bahwa pengumpulan data dengan cara dokumentasi merupakan suatu hal dilakukan oleh peneliti guna mengumpulkan data dari berbagai hal media cetak membahas mengenai narasumber yang akan diteliti. Penelitian ini menggunakan metode dokumentasi untuk mencari data tentang kegiatan siswa kelas VII SMP Santa Lusia Sei Rotan dalam merepresentasi tokoh wanita dalam cerpen.

HASIL PENELITIAN DAN PEMBAHASAN

Hasil dan pembahasan diperoleh sebagai berikut:

\section{a. Analisis unsur intrinsik Cerpen Martini \\ Penelitian terhadap cerpen Martini,} dilihat dengan analisis struktur internal cerpen tersebut sebagai langkah awal dalam penelitian ini. Unsur-unsur intrinsik dari cerpen Martini adalah sebagai berikut

\section{Tema}

Tema merupakan inti atau ide dasar sebuah cerita. Maka tema dari cerpen Martini ini adalah percayalah pada niat baikmu, karena dari awal cerpen Martini menceritakan tentang niat baik seorang istri terhadap keluarganya untuk membantu perekonomian keluarganya, dikisahkan juga bahwa Martini benar-benar percaya terhadap keluarganya khususnya kepada suaminya sehingga dia selalu menanamkan sifat positif (huznuzon), tidak 
ingin berpikir negatif terhadap keluarganya.

\section{Alur/plot}

Alur merupakan jalan cerita atau pola pengembangan cerita yang terbentuk dari hubungan sebabakibat. Alur cerpen Martini adalah alur maju, karena jalan cerita dijalankan secara runtut yaitu mulai dari perkenalan tokoh, bekerja keluar negeri, pulang ke Indonesia, dan dalam perjalanan pulang kekampung halamannya si tokoh bermimpi yang dalam mimpinya muncul pertentangan dan berlanjut ke konflik dan sampai penyelesaian dari konflik itu.

10. Latar/setting

Latar merupakan tempat, waktu, dan suasana terjadinya cerita. Maka latar dari cerpen Martini ini adalah:

a. Tempat :

1) Arab Saudi (Ia membayangkan putranya kini telah duduk dibangku SD mengenakan seragam putih-merah dan menempati rumahnya yang baru, yang dibangun oleh suaminya dengan uang dikirimkan dari Arab Saudi, Negara dimana selama ini ia bekerja.)

2) Bandara soekarno Hatta (akhirnya ia memutuskan untuk menuju terminal pulogadung dengan taksi bandara. Oleh karena ia tidak tahu dimana pool bus maju lancar terdekat dari Bandara Soekarno-Hatta....)

3) Terminal Pulogadung (...ia berharap diterminal Pulogadung ia bisa langsung menemukan bus...)
4) Dalam bus (Mbak-mbak bangun mbak. Turun dimana mbak.....)

5) Kampung halaman Martini yaitu Wonosari (Apakah benar ini Wonosari? Tanya Martini memastikan seraya mengarahkan pandangannya keluar jendela...)

6) Rumah (tanpa ia sadari, Martini telah sampai di depan rumahnya, rumah yang merupakan warisan ayahnya, yang ia huni bersama Mas Koko, Andra dan ibunya yang telah renta).

b. Waktu : (1) setelah tiga tahun ia meninggalkan kampung halamannya yang berjarak tiga kilometer dari arah selatan Wonosari Gunung Kidul. (2)... tanya Martini memastikan seraya mengarahkan pandangannya keluar jendela. Ya ini adalah daerah yang telah tiga tahun ia tinggalkan...

c. Suasana : dari awal cerita suasana biasa-biasa saja, tetapi pada pertengahan cerita terjadi konflik melalui mimpi si tokoh utama hingga menimbulkan suasana yang menegangkan.

11. Tokoh/penokohan

Tokoh adalah orang yang mempunyai peran dalam suatu karya sastra. Penokohan adalah cara pengarang menggambarkan dan mengembangkan karakter tokoh-tokoh dalam cerita.

Tokoh : Martini (Tokoh utama) Mbok (ibu Martini) Andra (anak Martini) Mas Koko ( Suami Martini) Istri baru

Penokohan :

a. Martini : 
1) Pekerja keras

Ia bekerja sebagai seorang pembantu rumah tangga di El Riyadh dengan tugas khusus mengasuh putra sang majikan yang sebaya denganAndra putranya. Hal ini membuatnya selalu teringat dengan puteranya sendiri dan menambah semangat dalam bekerja.

2) Teliti

Dengan cermat Martini memperhatikan sekeliling akan tetapi ia tidak melihat seorang saudara atau kerabatpun yang ia kenal.

3) Berpikir positif

a) Ia tidak ingin suuzon (berpikir negatif) dengan suaminya. Mungkin hal ini disebabkan karena kedatanganku yang memang terlambat tiga hari dari jadwal kepulangan yang direncanakan sebelumnya pikirnya huznuzun (berpikir positif)...

b) Apakah ia membeli tanah ditempat lain dan membangunnya disana. Kalau begitu syukurlah, pikirnya mencoba huznuzon...

4) Penurut

Martini menurut saja apa yang dikatakan ibunya...

5) Tidak sabar "Minumlah air putih ini agar kamu lebih tenang, nanti simbok ceritakan di mana suamimu berada, kalau kamu memang sudah tidak sabar".

6) Pemarah

a) Mendengar penuturan ibunya,

Martini langsung menangis, ia sedih marah dan kalut.

b) "Mbok, di mana Mbok", suara Martini semakin meninggi, namun ibunya tetap diam. "Kenapa simbok tidak mau memberitahu, apakah Simbok merestuinya? apakah Simbok mendukungnya?

apakah Simbok membela bajingan itu daripada saya anakmu sendiri?...

c) "Hei, mana Koko bajingan sialan, teriak Martini sambil berjalan membabi buta, menyusuri jalan dengan muka merah padam.

d) Martini yang dulunya lembut, penurut kini kasar dan beringasan...

e) Hal ini jelas membuat Tini makin marah. Hai, dasar kau wanita murahan, tidak tahu diri. Koko adalah suamiku dan kau koko, mengapa kau tega menipuku, meninggalkanku hanya untuk menikahi wanita keparat ini. Dasar bajingan."

7) Setia

"Buat apa aku bekerja jauh-jauh mencari uang di Arab Saudi demi kamu dan Andra tetapi mengapa kau tega memanfaatkanku, menggunakan uangku untuk membuat rumah dan tinggal di sana bersama istri barumu, Kurang apa aku?"... 
8) Kuat

Namun dengan kuat

Martini mencoba

melepaskan tangannya

dari dekapan tetangganva

itu dan saat itu pula ia

melihat suaminya,

9) Lembut

Martini yang dulunya

lembut, penurut kini kasar dan beringasan...

10) Tidak hati-hati

Dengan tidak hati-hati ia menaiki anak tangga yang menuju kedalam rumah baru itu. Secepat kilat ia mengayunkan bambu itu ke arah mereka berdua. Namun malang, belum sampai bamboo itu mengenai sasaran, ia kehilangan keseimbangan.

11) Sabar

Hal ini ditunjukkan dari penjelasan tokoh, penggambaran fisik tokoh serta tanggapan tokoh lain terhadap tokoh utama.

b. Mbok :

1) Tidak terus terang

$\mathrm{Oh}$ mengenai suamimu, nanti akan simbok ceritakan, sebaiknya kamu ngaso dulu.

2) Perhatian

...Kau pasti capek setelah melakukan perjalanan jauh. Jangan lupa teh hangatnya di minum dulu.

3) Tua-lemah

Namun apa daya, simbok hanyalah wanita yang sudah renta, sedang ayahmu sudah tiada, dan uang yang simbok pegang pun pas-pasan.

4) Sabar

Dari cerita tersebut dapat diketahui bahwa ibu
Martini adalah sosok yang sabar karena dia berusaha hidup berpasrah kepada Tuhan.

c. Andra

1) Sopan

Madosi sinten mbak?"

Tanya seorang bocah

berusia 6 tahun yang tak lain adalah andra yang muncul dari balik pintu.

2) Patuh terhadap orang tua

Diikuti oleh Andra , membawakan segelas teh hangat.

d. Koko

Tidak bertanggung jawab terhadap keluarga dan tidak setia terhadap keluarga. Dari cerpen Martini, sangat jelas bahwa Koko adalah laki-laki yang tidak bertanggung jawab terhadap keluarga karena dia tidak mau mencari pekerjaan dan hanya makan gaji buta saja yang dikirimkan oleh istrinya dari luar negeri serta menikah dengan perempuan lain. Seharusnya sebagai kepala keluarga dia berusaha untuk memenuhi kebutuhan keluarganya.

e. Istri baru

1) Perebut laki orang

Bahkan istri barunya itu terlihat dengan mesranya berdiri disamping koko yang meletakkan kedua tangannya dipinggang koko. "Hei, siapa kamu. Tini ya. Kenapa kamu kesini? Ini rumahku bersama mas koko. Bukannya kamu sudah mati, kalau belum mendingan kamu mati saja sekarang. Itu lebih baik, dari pada mau merusak kebahagiaan kami. Bukan begitu mas Koko?" ujar 
wanita yang ada disebelah

Koko sambil

mengalungkan tangan

kanannya dileher koko dengan lembutnya.

2) Tidak peduli

Bahkan istri barunya itu terlihat dengan mesranya berdiri disamping koko yang meletakkan kedua tangannya dipinggang koko." Hei, siapa kamu. Tini ya. Kenapa kamu kesini? Ini rumahku bersama mas koko. Bukannya kamu sudah mati, kalau belum mendingan kamu mati saja sekarang. Itu lebih baik, dari pada mau merusak kebahagiaan kami. Bukan begitu mas Koko?" ujar wanita yang ada disebelah Koko sambil mengalungkan tangan kanannya dileher koko dengan lembutnya.

3) Kasar

Bahkan istri barunya itu terlihat dengan mesranya berdiri disamping koko yang meletakkan kedua tangannya dipinggang koko. " Hei, siapa kamu. Tini ya. Kenapa kamu kesini? Ini rumahku bersama mas koko. Bukannya kamu sudah mati, kalau belum mendingan kamu mati saja sekarang. Itu lebih baik, dari pada mau merusak kebahagiaan kami. Bukan begitu mas Koko?" ujar wanita yang ada disebelah Koko sambil mengalungkan tangan kanannya dileher koko dengan lembutnya.

12. Sudut pandang
Sudut pandang atau point of view adalah posisi pengarang dalam membawakan cerita. Sudut pandang dari cerpen Martini ini adalah sudut pandang orang ketiga karena itu terlihat bahwa pengarang menggunakan kata ganti "Ia, dia, atau nama dari pelaku dalam karya satra" untuk menunjuk para tokoh yang bermain dalam cerita (kini ia kembali menginjakkan kakinya di Indonesia setelah tiga tahun ia meninggalkan kampung halamannya...).

\section{Amanat}

Amanat merupakan ajaran moral atau pesan yang hendak disampaikan pengarang kepada pembaca melalui karya sastra. Maka amanat dari cerpen ini adalah jangan menyerah dalam memperjuangkan kehidupan yang diberikan Tuhan kepada kita, sebagai seorang suami harus bertanggung jawab terhadap keluarga memenuhi kebutuhan nafkah keluarga, mari bersifat positif dalam kehidupan kita, kesabaran dan keuletan dalam menjalani kehidupan akan membuahkan hasil yang baik, selalu berniat baik untuk mendapatkan berkat yang berlimpah yang berasal dari Tuhan.

14. Gaya bahasa

Dalam cerita, penggunaan bahasa berfungsi untuk menciptakan suatu nada atau suasana persuasif serta merumuskan dialog yang mampu memperlihatkan hubungan dan interaksi antara sesama tokoh. Gaya bahasa memungkinkan kita dapat menilai pribadi, tokoh, dan kemampuan seseorang mempergunakan bahasa itu. Semakin baik gaya bahasanya, semakin baik pula penilaian orang terhadapnya 
semakin buruk gaya bahasa seseorang, semakin buruk pula penilaian diberikan kepadanya. Maka gaya bahasa dari cerpen Martini ini adalah mengalir dan mudah dipahami.

b. Representasi Tokoh Wanita dalam Cerpen Martini oleh Siswa Kelas VII-1 SMP Swasta Santa Lusia Sei Rotan Tahun Pelajaran 2017/2018

Berdasarkan penelitian yang sudah dilaksanakan, maka representasi tokoh wanita dalam cerpen Martini adalah :

\section{Representasi tokoh Martini}

Dari hasil penelitian dan analisis kelas VII-1SMP Swasta Santa Lusia, dapat disimpulkan bahwa lebih dari setengah siswa mengatakan bahwa represetasi tokoh Martini dalam cerpen adalah sebagai berikut:

a. Wanita itu pekerja keras

Semua siswa mengatakan bahwa Wanita bekerja keras untuk memenuhi kebutuhan sendiri dan menafkahi keluarganya. Perempuan juga memiliki peran ganda selain mengurusi pekerjaan domestik (rumah), perempuan juga membantu dalam produktifitas perekonomian keluarga. Sosok wanita pekerja keras seperti yang dikisahkan dalam cerpen Martini.

"Martini adalah seorang
tenaga wanita yang berhasil
diantara banyak kisah
mengenai tenaga kerja wanita
yang nasibnya kurang
beruntung".

Dari kutipan cerpen tersebut ditampakkan sosok wanita pekerja keras yang artinya Martini berusaha bekerja dengan sebaik mungkin agar ia bisa membantu perekonomian keluarganya.

b. Wanita itu lembut

Arti kata lemah lembut adalah rapuh hati, tidak keras hati. Orang yang lamah lembut akan berbicara dengan sopan dan tidak kasar tapi ia tetap berpegang teguh dalam prinsip. seperti halnya dalam cerpen Martini dikatakan bahwa Martini itu lemah lembut.

"Martini yang dulunya lembut, penurut, kini kasar dan beringasan".

Dari kutipan teks cerpen tersebut dapat kita ketahui bahwa manusia yang diciptakan Tuhan baik itu laki-laki maupun wanita diciptakan sesuai dengan karakter masingmasing. Laki-laki mempunyai karakter kasar, kuat dan sebagainya sedangkan wanita kebalikan dari karakter laki-laki yaitu lemah lembut, feminim dan lain sebagainya.

c. Wanita itu tabah dan sabar

Arti kata tabah adalah tetap dan kuat hati. Wanita berbeda dengan lelaki wanita biasanya lebih tabah menghadapi segala persoalan hidup daripada lelaki. Contoh wanita yang tabah adalah seperti Martini.

"Martini adalah seorang tenaga wanita yang berhasil diantara banyak kisah mengenai tenaga kerja wanita yang nasibnya kurang beruntung".

Dari kutipan teks itu dapat kita ketahui bahwa Martini tabah dalam menjalani hidupnya, berusaha kuat hati dalam menjalani hidup, menjadi TKW di negeri orang, meninggalkan keluarganya selama tiga tahun.

Arti kata sabar adalah suatu sikap yang mampu menahan emosi dan keinginan, serta bertahan dalam situasi sulit, sabar itu juga merupakan kemampuan mengendalikan diri yang juga dipandang sebagai sikap yang mempunyai nilai tinggi dan mencerminkan kekokohan jiwa orang yang memilikinya. Tokoh Martini dan juga Mbok (ibu Martini) telah mencerminkan sifat sabar. Hal ini ditunjukkan dari penjelasan tokoh, penggambaran 
fisik tokoh serta tanggapan tokoh lain terhadap tokoh, dan itu tampak dalam kutipan teks berikut:

"Duh Gusti..., paringono
sabar...,." terdengar Martini
terisak, berusaha untuk tetap
ingat kepada Yang Maha Kuasa".

d. Wanita itu Penurut

Dalam KBBI kata penurut artinya orang yang suka menurut, tidak melawan dan orang yang patuh. Penurut juga bukan berarti ikut arus dalam arti mudah terpengaruh tetapi lebih kepada hal yang positif. Untuk menjadi orang yang penurut untuk zaman sekarang itu bukanlah hal yang mudah, tetapi dalam cerpen Martini telah ditampakkan sifat penurutnya terhadap suami dan juga kepada orang tuanya.

"Martini yang dulunya lembut, penurut, kini kasar dan beringasan".

e. Berpikir positif

Berpikir positif secara harafiah berarti tidak berpikir negatif. Berpikir positif berarti cara berpikir yang logis yang memandang sesuatu dari segi positifnya saja, baik itu terhadap diri, orang lain maupun dengan keadaan lingkungan sekitarnya. Dalam cerpen Martini ditunjukkan bahwa Martini yang selalu berusaha berpikir positif akan segala sesuatu yang dialaminya. Seperti yang tertulis dalam teks berikut :

"Namun dengan segera ia membuang jauh - jauh pikiran tersebut. Ia tidak ingin suuzon (berpikir negatif) dengan suaminya. "mungkin hal ini disebabkan karena kedatanganku yang memang terlambat tiga hari dari jadwal kepulangan yang direncanakan sebelumnya," pikirnyahuznuzon (berpikir positif)".

f. Wanita itu Setia
Dalam Kamus besar Bahasa Indonesia Online, setia berarti berpegang teguh pada janji, pendirian dan pada persahabatan. Martini adalah sosok yang setia terhadap keluarganya, walaupun dia tinggal jauh dari keluarganya dia tetap memegang teguh akan pendiriannya, seperti yang ditunjukkan dalam kutipan teks cerpen berikut yang didalamnya terkandung makna kesetiaan.

Teks 1

"Didalam benak Martini berbaur rasa senang, rindu dan haru. Beberapa jam lagi ia akan berjumpa kembali dengan suaminya,...".

Teks 2

"Buat apa aku bekerja jauh-jauh mencari uang di Arab Saudi demi kamu dan Andra tetapi mengapa kau tega memanfaatkanku, menggunakan uangku untuk membuat rumah dan tinggal di sana bersama istri barumu, Kurang apa aku?...".

g. Wanita juga pemarah

Marah adalah suatu emosi yang muncul akibat sesuatu yang tidak menyenangkan, menyakitkan, rasa kecewa. Pemarah adalah orang yang lekas marah. Dalam cerpen Martini ditunjukkan juga Sikap Martini yang pemarah yaitu yang terdapat dalam kutipan teks berikut

Teks 1 "Hei, mana Koko, bajingan sialan,"teriak Martini sambil berjalan membabi buta, menyusuri jalan dengan muka merah Padam...".

Teks 2 "Mendengar penuturan ibunya, Martini langsung menangis, ia sedih marah dan kalut...".

\section{Representasi tokoh Mbok (Ibu} Martini) 
Dari hasil penelitian dan analisis kelas VII-1 SMP Swasta Santa Lusia, dapat disimpulkan bahwa lebih dari setengah siswa mengatakan bahwa represetasi tokoh Mbok (Ibu Martini) dalam cerpen adalah sebagai berikut:

a. Tidak terus terang

Tidak terus terang berarti tidak jujur. Tetapi dalam hal ini lebih kepada ketakutan dalam mengungkapkan atau bisa dikatakan menjaga perasaan orang lain. seperti yang dikisahkan dalam cerpen ini, Ibu Martini takut mengungkapkan kebenaran kepada si Martini, seperti yang diungkapkan dalam kutipan teks cerpen berikut:

Teks 1

Mendengar pertanyaan itu, tiba-tiba air muka ibu Martini berubah, ia tampak berpikir pikir sejenak. " Oh mengenai suamimu, nanti akan simbok ceritakan, sebaiknya kamu ngaso dulu.

Teks 2

Ibu Martini tampak kembali berfikir sejenak, lalu berdiri dan mengambil segelas air putih dingin dari kendi. "minumlah air putih ini agar kamu lebih tenang, Tini, nanti simbok ceritakan di mana suamimu berada, kalau kamu memang sudah tidak sabar."

b. Sabar

Arti kata sabar adalah suatu sikap yang mampu menahan emosi dan keinginan, serta bertahan dalam situasi sulit, sabar itu juga merupakan kemampuan mengendalikan diri yang juga dipandang sebagai sikap yang mempunyai nilai tinggi dan mencerminkan kekokohan jiwa orang yang memilikinya. Mbok (ibu Martini) telah mencerminkan sifat sabar, dalam menjalani kehidupan.
"Diam Tini, teganya kamu menuduh ibumu seperti itu. Kamu mau menjadi anak durhaka? Ingatlah kamu kepada Tuhan, Nak, ingatlah kepadaGusti Allah, Nak" Kalimat itu muncul dari mulut ibunya, yang kemudian terduduk menangis

mendengar ucapan pedas anaknya tersebut.

c. Lemah-lembut

Arti kata lemah lembut adalah rapuh hati, tidak keras hati. Orang yang lamah lembut akan berbicara dengan sopan dan tidak kasar tapi ia tetap berpegang teguh dalam prinsip. Teks yang menunjukkan bahwa ibu Martini lemah-lembut adalah :

Teks 1

"Namun apa daya, simbok hanyalah wanita yang sudah renta, sedang ayahmu sudah tiada, dan uang yang simbok pegang pun pas - pasan. Mau mengirim surat kepadamu simbok tidak bisa, kamu tahukan simbok buta huruf. Mau minta tolong kepada siapa lagi, sedangkan kamu adalah anakku satu - satunya".

\section{Teks 2}

"Tini akan cari sendiri rumah itu, "teriak Martini" seraya meninggalkan ibunya yang sangat bersedih, yang berusaha mengejarnya namun kemudian jatuhtersungkur di halam depan rumahnya karena tidak mampu lagi mengejarnya".

\section{Representasi tokoh Istri Baru}

Dari hasil penelitian dan analisis kelas VII-1 SMP Swasta Santa Lusia, dapat disimpulkan bahwa lebih dari setengah siswa mengatakan bahwa represetasi tokoh Istri Baru dalam cerpen adalah sebagai berikut:

a. Pelakor (Perebut laki orang)

Dalam cerpen diungkapkan bahwa isteri baru Koko adalah seorang pelakor karena dia sudah tahu bahwa suaminya itu mempunyai 
isteri, tapi karena dia adalah orang yang tidak peduli akhirnya ia pun menikah dengan suami Martini.

"Bahkan istri barunya itu terlihat dengan mesranya berdiri disamping koko yang meletakkan kedua tangannya dipinggang koko. " Hei, siapa kamu. Tini ya. Kenapa kamu kesini? Ini rumahku bersama mas koko. Bukannya kamu sudah mati, kalau belum mendingan kamu mati saja sekarang. Itu lebih baik, dari pada mau merusak kebahagiaan kami. Bukan begitu mas Koko?" ujar wanita yang ada disebelah Koko sambil mengalungkan tangan kanannya dileher koko dengan lembutnya".

b. Kasar

Arti kata kasar adalah tidak halus, besar-besar, tidak sesuai tata krama atau sopan santun. Pada umumnya sifat perempuan adalah halus, tetapi tidak bisa juga dipungkiri bahwa kadang kala wanita itu juga kasar seperti yang diungkapkan dalan cerpen Martini, yaitu isteri baru dari suami Martini yang begitu kasar.

Teks

Bahkan istri barunya itu terlihat dengan mesranya berdiri disamping koko yang meletakkan kedua tangannya dipinggang koko. "

Hei, siapa kamu. Tini ya. Kenapa kamu kesini? Ini rumahku bersama mas koko. Bukannya kamu sudah mati, kalau belum mendingan kamu mati saja sekarang. Itu lebih baik, dari pada mau merusak kebahagiaan kami. Bukan begitu mas Koko?" ujar wanita yang ada disebelah Koko sambil mengalungkan tangan kanannya dileher koko dengan lembutnya.

Kutipan teks cerpen diatas menunjukkan kekasaran si isteri baru kepada Martini. Hal ini menyatakan bahwa memang tidak semua wanita itu halus dan feminin tapi juga mempunyai sifat yang kasar dan tomboy.

c. Tidak peduli

Tidak peduli adalah sikap yang tidak memperhatikan orang lain atau orang yang tidak peduli dengan dunia sekitarnya, seperti yang diungkapkan dalam cerpen ini, yaitu Isteri baru Koko yang benar-benar tidak peduli dengan Martini.

Teks

Bahkan istri barunya itu terlihat dengan mesranya berdiri disamping koko yang meletakkan kedua tangannya dipinggang koko. ', Hei, siapa kamu. Tini ya. Kenapa kamu kesini? Ini rumahku bersama mas koko. Bukannya kamu sudah mati, kalau belum mendingan kamu mati saja sekarang. Itu lebih baik, dari pada mau merusak kebahagiaan kami. Bukan begitu mas Koko?" ujar wanita yang ada disebelah Koko sambil mengalungkan tangan kanannya dileher koko dengan lembutnya.

Dari hasil penelitian dan juga hasil representasi tokoh wanita dalam cerpen Martini diatas dapat disimpulkan bahwa pada dasarnya wanita itu mempunyai sikap positif dan juga sifat negatif, tergantung bagaimana seseorang mengembangkan pribadinya.

\section{SIMPULAN}

Dari hasil penelitian dan juga hasil representasi tokoh wanita dalam cerpen Martini diatas dapat disimpulkan bahwa pada dasarnya wanita itu mempunyai sikap positif dan juga sifat negatif, tergantung bagaimana seseorang mengembangkan pribadinya. Maka yang menjadi representasi tokoh wanita dalam cerpen Martini adalah :

a. Representasi tokoh Martini dikatakan bahwa wanita itu pekerja keras, lembut, sabar dan tabah, penurut, berpikir positif, setia, dan juga pemarah. 
b. Representasi tokoh Mbok (Ibu Martini) dalam cerpen dikatakan bahwa wanita itu tidak mau terus terang, sabar, dan lemah lembut.

c. Representasi tokoh Istri baru dalam cerpen adalah bahwa wanita itu seorang perebut laki orang, kasar dan tidak peduli.

\section{DAFTAR KEPUSTAKAAN}

Ahmad, Wintala. 2015. Menjadi Penulis Handal : Karya Ilmiah, Artikel, Resensi, Naskah Drama, Puisi, Cerpen, dan Novel. Yogyakarta: Araska.

Al Bukhari, Jefri, H. 2016. Ada Apa dengan Wanita. Jakarta Selatan: AMP Press AL-Mawardi Prima

Arikunto, Suharsimi. 2006. Prosedur Penelitian suatu Pendekatan Praktik. Jakarta: Rineka Cipta

Eriyanto. 2001. Analisis Wacana: Pengantar Analisis Teks Media. Yogjakarta: Lkis.

(http://m4hakim.blogspot.com/2014/08/ha sgyudoaysulizl.html:1), 12 Maret 2018

Kosasih, E. 2011. Ketatabahasaan dan Kesusastraan. Bandung: Yrama Widya.

Marliah, Siti. 2016. Karakterisasi Tokoh Utama dalam Kumpulan Cerpen Celeng Satu Celeng Semua Karya $\mathrm{Tr}$ iyanto Triwikromo dan Pembelajarannya di SMA. Diakses tanggal 21 Februari 2018.

Moleong. 2016. Metode Penelitian Kualitatif. Bandung: PT Remaja Rosdakarya.

Nina,Johan.2012. Perempuan Nuaulu: Tradisionalisme dan Kultur Patriarki. Jakarta: Yayasan Pustaka Obor Indonesia.

Sukmadinata, Nana Syaodih. 2012.Metode Penelitian Pendidikan. Bandung: Remaja Rosdakarya.

Sugiyono. 2010. Metode Penelitian Kuantitatif, Kualitatif, dan $R \& D$. Bandung: Alfabeta.
Sugiyono. 2016. Metode Penelitian Pendidikan Pendekatan Kuantitatif, Kualitatif, dan $R \& D$. Bandung: Alfabeta.

Sugiyono. 2017. Metode Penelitian kuantitatif, Kualitatif, dan $R \& D$. Bandung: Alfabeta

Syam, Nutrisia, Ayu, Tri. 2013. Representasi Nilai Feminisme Tokoh Nyai Ontosoroh dalam Novel Bumi Manusia Karya Pramoedya Ananta Toer Sebuah Analisis Wacana. Diakses tanggal 23 Februari 2018.

Tarigan, Hendry Guntur. 2016. Prinsipprinsip Dasar Sastra. Bandung: Angkasa.

Wibowo, Adi, Eviyono. 2015. Representasi Perempuan dalam Film Wanita Tetap Wanita (Analisis Semiotika Representasi Perempuan dalam Film Wanita Tetap Wanita). Diakses pada tanggal 23 Februari 2018. 